https://doi.org/10.31426/ijamsr.2018.1.3.131

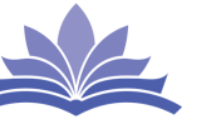

I J A M S R

International Journal of

Advanced Multidisciplinary Scientific Research (IJAMSR) ISSN:2581-4281

\title{
TAPPING INTO REVIEWS OF TOURISTS’ EXPERIENCES IN LAKE TOBA
}

\author{
Dr. Azila Azmi ${ }^{1 *}$, Dian Aszyanti Atirah Mohd Asri², Hanani Ahmad Zubir ${ }^{3}$ \\ Dr. Ahmad Rasmi Albattat ${ }^{4}$
}

Senior Lecturer , Dept.of.Tourism Management, Universiti Teknologi MARA, Malaysial

Lecturer, Dept.of.Hotel Management, Universiti Teknologi MARA, Malaysia ${ }^{2}$

Senior Lecturer,Academy of Language Studies, Universiti Teknologi MARA, Malaysia ${ }^{3}$

Asst.Professor of Hotel Management, Ammon Applied Unviersity College, Jordan ${ }^{4}$ azila.azmi@ppinang.uitm.edu.my

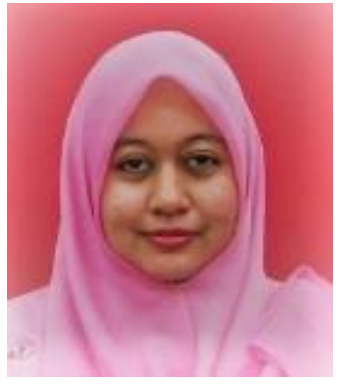

Dr. AzILA AZMI

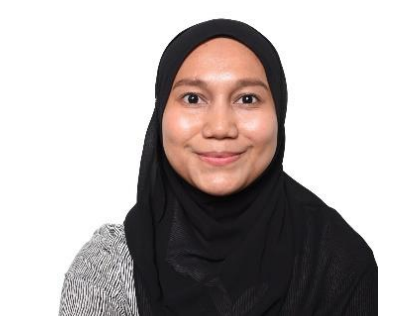

DIAN ASZYANTI ATIRAH MOHD ASRI

Keywords: Lake tourism; content analysis; tourist experiences; Lake Toba

\begin{abstract}
A B S T R A C T
This research focuses on a content analysis study of Lake Toba, which is located in the province of North Sumatera. As one of the largest volcanoes-tectonic lakes in the world and the biggest lake in Southeast Asia, Lake Toba is visited by both local and international tourists. Most of the tourists who visited the lake shared their experience in several online review platforms, namely TripAdvisor. Hence, the data in this study were analyzed qualitatively using content analysis with thematic coding. The sample used in this study is taken from the TripAdvisor forum. The result of this study highlighted natural and cultural attractions as the two utmost experiences shared by the tourists while visiting Lake Toba. In terms of natural attractions, most of the tourists were fascinated by the breathtaking views of Lake Toba and engaged themselves with several outdoor activities. Meanwhile, for the cultural attractions, the tourists were captivated by the distinct cultures and practices of the Batak community. The findings of this study suggested that the management, local community, and government agency must play a vital role in sustaining Lake Toba as a tourism destination.
\end{abstract}

Citation: Dr. Azila Azmi, Dian Aszyanti Atirah Mohd Asri, Hanani Ahmad Zubir, Dr. Ahmad Rasmi Albattat (2018). Tapping Into Reviews Of Tourists' Experiences In Lake Toba. International Journal of Advanced Multidisciplinary Scientific Research (IJAMSR ) ISSN:2581-4281 Vol 1, Issue 3, May, 2018, \#Art.131, pp24-29

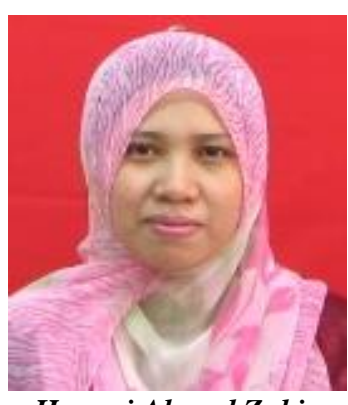

Hanani Ahmad Zubir

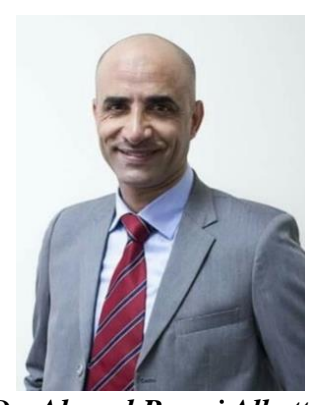

Dr. Ahmad Rasmi Albattat 


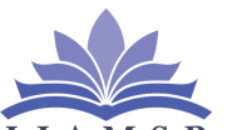

I J A M S R

\section{International Journal of}

\subsection{Introduction}

Lake Toba or 'Danau Toba' in Indonesia is the biggest volcanic lake in the world. It is $100 \mathrm{~km}$ in length and $30 \mathrm{~km}$ in width, and its depth is $505 \mathrm{~m}$. It is situated in the middle of the northern part of Indonesia, Sumatra Island. The amazing Lake Toba cannot be shown through pictures or described with words. The scenery of Lake Toba with the hills encompassing the lake and the crisp air, this would enable the visitors to relax their mind. Obviously, Lake Toba in North Sumatra is a popular destination for local and foreign tourists. The government of Indonesia expects foreign arrivals to Lake Toba to increase from 250,000 to 1 million people over the next four years (The Jakarta Post, 2017). There are many development projects, as well as promotional efforts carried out by the Ministry of Tourism Indonesia, aiming to welcome the international tourists to Lake Toba, thus, generating tourism revenue for the country. Therefore, in supporting the ministry's efforts, this study attempts to explore and analyze tourists' experiences in Lake Toba as a tourism destination.

Hitherto, there is a scarcity of documented information on tourists' experiences towards this well-known tourist attraction in Indonesia. The majority of the previous studies were focusing on the geographical area of Lake Toba, but not on tourists' experiences (Lumbanraja, 2012; Situmeang, 2016; Saragih \& Sunito, 2001; Johnson, 1956). Thus, this study explores the tourists' experiences in Lake Toba by using content analysis of online review. These days, online reviews provide convenience for the tourists to have a comprehensive understanding of attractions and make decisions, however, the availability of hundreds online reviews create a problem in tourists' decision making. Hence, to be certain, potential travelers look at reviews on several tourism websites, such as TripAdvisor (http://www.tripadvisor.com/), Facebook Fan Page, and Travel Blog. Among all the three websites, TripAdvisor displayed more tourists' reviews as compared to the other two because TripAdvisor plays a dominant role in the online travel market and has continued to grow in popularity since its inception in 2000 (Law, 2006).

Recently, TripAdvisor has more than 700 reviews about Lake Toba and reading all the reviews seems impossible. This study will gather a few reviews based on the category rating including excellent, very good, and the least is average. In this study, TripAdvisor is chosen as the online review website to analyze the tourists' experiences in Lake Toba. One of the reasons that the tourists wrote their reviews are because reviews serve as a tool not only for tourists to decide, but also for tour operators to improve their service quality. Most of the time, the reviews have significant influence and are considered the most valuable reviews. The content is the most important factor that contributes to the value of a review, especially for attracting visitors, as information quality always seen critical in reducing uncertainty (Mudambi \& Schuff, 2010). Hence, the main purpose of this study is to analyze the reviews of the tourists' experiences in Lake Toba by emphasizing on TripAdvisor tourist's reviews. The reviews circuitously influence the attributes of Lake Toba as a tourism destination.

\subsection{Lake Tourism}

Extensively, lakes are identified by many countries and destinations in tourism promotional campaigns, whether it provides a key image of destination or an attractive backdrop for other leisure activities (Harkonen, 2003). Due to that, attention should be given to lake tourism as it falls under natural environment that promotes both tourism and recreational activities. There are many beautiful lakes in the world, such as Lake Como in Northern Italy, Maligne Lake in Canada, and Lake Pichola in India (Heiderstadt, 2013). Besides that, one of the largest volcanoes-tectonic lakes in the world are Lake Toba. The lake is located in the province of North Sumatra, $176 \mathrm{~km}$ to the west of the provincial capital, Medan. Lake Toba can be reached by car from Medan within three hours. By plane, Medan is 40 minutes away from Singapore and two hours from Jakarta, the capital city of Indonesia. The lake is one of the country's important tourist destinations with its position not only as one of the largest volcanic lakes in the world, but also as one of the biggest lakes in Southeast Asia.

\subsection{Lake Toba as Tourism Destination}

The beauty of Lake Toba has been internationally recognized. The lake's blue water, gracious community, and fascinating Batak culture draw tourists from all over the globe to the remote destination of Lake Toba (Moedjodo, Simanjuntak, \& Hehanussa, 1999). In addition, lakes are also an important resource for tourism development, based on their landscape features and cultural attractions. Lakes offers a naturally defined core resource for tourism development. Hall and Härkönen (2006) defined lake tourism as tourism that occurs not only on the lake itself, but also the foreshore and those amenities, facilities and infrastructure surrounding the lakes. Despites the natural and cultural resources around the lake, the general enchantment of lakes usually relates 


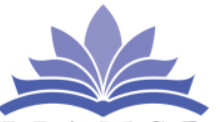

I J A M S R

International Journal of

Advanced Multidisciplinary Scientific Research (IJAMSR) ISSN:2581-4281

to human emotions and how it makes tourists feel is of utmost importance. Lake Toba has spectacular scenery, great activities, and rich culture of the sociable Batak people. The locals are friendly and tourists are not subject to any sort of racism.

Apart from the scenery of the lake, there is an island in Lake Toba called Samosir Island for the tourists to explore. The island is located in the middle of Lake Toba. The size of Samosir Island is almost the same as the size of Singapore. It is created by a smaller eruption between 30,000 and 75,000 years ago. At an elevation of 800 meters, the climate is comfortable and the setting is truly superb, making it a popular getaway in a perfect setting for those who simply looking forward to relax. Perhaps the best way to enjoy the stunning scenery around Parapat and Lake Toba is to take a cruise around the Samosir Island.

\subsection{Online Tourists' Reviews of Tourism Destination}

In particular, consumer reviews are important in learning about experience goods such as hotel rooms, as their quality is often unknown before purchase. Xie, Chen, and $\mathrm{Wu}$ (2016) indicated that online reviews offer quality information to reduce risk in purchasing experience goods. In presence of online reviews, consumers are able to learn the perception of product quality and service satisfaction from previous consumers without experiencing the goods by themselves.

Previous reviews by the tourists with regards to the evaluation and feedback of their experience in buying goods and services indirectly provide important reference for new customers to make prudent decisions and choose the products that best match their preference. Consequently, nowadays, about three-quarters of tourists have considered online consumer reviews when planning their travel itineraries (Xie et al. 2016), and nearly 50 percent of consumers visit an online review site for information connected to their online travel purchasing (Compete, 2006). Online consumer reviews have become an important source of information for consumers, substituting for other forms of business-toconsumer (Jiang \& Chen, 2007) and off-line word-ofmouth communication (Lewis \& Bridger, 2001) about the quality of service providers.

Nowadays, most social media platforms allow tourists to provide reviews and ratings to evaluate their experience with a product (Weng, Chu, \& Wu, 2009). According to Jeong and Jeon (2008), ratings for their part can be closely assimilated to an overall service evaluation. In that sense, the customer uses a single scale to express his or her judgment of the product experience. In tapping with the current trends, this study analyses the tourists' experiences visiting Lake Toba in one of the eminent tourists' review platform, the TripAdvisor.

\subsection{Methodology}

This study adopted qualitative approach whereby content analysis was used to analyze the data. TripAdvisor was used as a medium to accumulate the information. TripAdvisor is a travel site offering reviews of travelassociated substance. It also provides interactive travel forums known as TripAdvisor forums. The tourists' reviews after their post-visit to Lake Toba were analyzed in order to interpret their experiences and identify the theme of the study. The sample is based on traveler rating reviews which listed 707 reviews, ranging from excellent to average. Since the proportion of ratings has a big gap, in this study, only 30 reviews were selected based on 20 reviews from excellent and very good, while the other 10 reviews with average rating. This is partly due to the responses reached saturation points as the respondents keep repeating the similar information and no new information was found. To ensure confidentiality, reviewer's name is coded as 'Key Informant'. Their reviews were edited in terms of language in order to make sure they are clear and understandable. In addition, researchers review related journals, books, and articles to provide an insight view of the study.

\subsection{Results and Discussion}

Tourists visiting Lake Toba are apparently engaged in two categories of attractions which are natural and cultural attractions. For that reason, this study, groups the experiences the tourists had in Lake Toba into two main themed; natural attraction and cultural attractions.

\subsection{Theme 1: Natural Attraction}

The majority of the tourists had classified Lake Toba as the best place to rest and relax. The tourists were immersed in their own fascination of the lake as they picnic or walk by the lake. Those tourists who love the natural environment were amazed with the magnificent views of Lake Toba. Out on the lake, most of the tourists appreciate the natural beauty of Lake Toba.

Other than seeing the beautiful lake, most of them also enjoy swimming there and some reviewed that the lake 


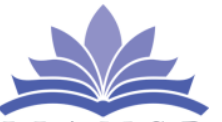

I J A M S R

\section{International Journal of}

Advanced Multidisciplinary Scientific Research (IJAMSR) ISSN:2581-4281

is safe and the water is clean. The tourists could also swim in the fresh water of the lake right at the doorstep of their lakeside resort because fantastic accommodation is provided. If swimming is not the choice, there are other water activities available such as jet-skiing and kayaking. The kayak can be easily rented by the local community and with just a paddle away the tourist will be spoiled by the views of volcanic mountains touching the sky above.

Besides enjoying the breathtaking scenery of Lake Toba, most of the tourists are also able to witness the amazing 120-meter-tall waterfalls name Sipiso-Piso. The waterfall is on the northern edge of Lake Toba. Tourists are allowed to hike up the waterfall for an amazing view of the surrounding landscape. Another nice waterfall near to the lake is the Binangalom Waterfall, which cascades into the lake. Tourists perceived it as a great spot for a refreshing swim on a hot day and among one of the best things to do at Lake Toba.

Subsequently, most of the tourists observed that the nature environment could never be separated from Lake Toba. A hot spring that is located at the foot of Pusuk Buhit is also one of the elements of nature attractions. Some of the hot springs have been funnelled into small swimming pools where tourists can soak in the water and relax. They are cheap and very rudimentary pools, but an interesting place to visit for those who can cope with the hot temperature of the water.

Moreover, the adventurous and outgoing tourists can experience numerous exploratory activities. Sumatra has numerous active and dormant volcanoes and Lake Toba is a huge one by itself. Some of the tourists challenge themselves by taking a hike to the peak of one of the dormant volcanoes. Besides the volcano's peak, tourists also join climbing activities at Mount Sibayak. Popular with locals and foreigners alike, Mount Sibayak is located near the town of Berastagi, just two hours north of Lake Toba. Apart from the hiking activities, tourists who visit Lake Toba also engage themselves in other outdoor activities, such as cycling and Paragliding around the lake.

Some of the tourists' reviews that contribute to the emergence of the theme natural attractions are as follows:

Every angle from side to side, either east, west, north, south and top side, always giving you a wonderful view. Seeing is believing. Come and enjoy! (Key Informant 3)
Lake Toba have a great view of nature, no matter what time you visit there morning to evening it always have great view and clean air. Easy to take a bite, to pray, and to ride various transportations to Samosir Island, the hotel is also cheap and affordable. (Key Informant 25)

A beautiful place with amazing scenery, from stunning waterfalls to the huge lake in the middle of the crater of a super volcano. A beautiful place and definitely worth seeing. (Key Informant 5)

What I love most here in Toba Lake is the atmosphere. The climate is also good at night, around $23^{\circ} \mathrm{C}$ and day time is $28-30^{\circ} \mathrm{C}$, we were there for 2 nights. If you like to soak your body in the water, that would be great, there are a lot of water activities, for example jet skiing. (Key Informant 14)

One of the greatest places in the world. You should visit the lake before you die. Specially for photographers, there are many available spots to take awesome photos. (Key Informant 21)

I couldn't believe that it was actually a lake, it is so huge! And has simply exquisite natural beauty, hills surrounding it! Absolutely breathtaking! The island in the lake was a bit disappointing, but other than that everything was perfect! (Key Informant 6)

This is the place suitable for those love outdoor activities, vegetation experience, serenity and green environment. The jungle trekking and cool wind plus awesome view... (Key Informant 8)

A very beautiful place to visit when you plan to escape your routines. Take a great swim in the lake because it is not seawater. Or just enjoy the balloon rides around Samosir Island to get adrenaline boost! (Key Informant 5)

Such a lovely place for a break from life... perfect for trip with either friends or families! You would enjoy so many outdoor activities here, from cycling, swimming, Paragliding, and jet skiing. (Key Informant 2)

\subsection{Theme 2: Cultural Attractions}

Besides enjoying the nature, some of the tourists are captivated by the culture attractions in Lake Toba. There are various cultural activities could be done surrounding the lake, thus it helps in promoting Lake Toba as a cultural tourist destination. The area surrounding Lake Toba is inhabited by an ethnic group known as the Bataks, whose traditions and lifestyles are generally 


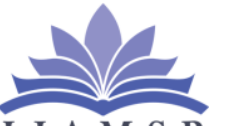

I J A M S R

\section{International Journal of}

Advanced Multidisciplinary Scientific Research (IJAMSR) ISSN:2581-4281

different from the rest of Indonesia. The large majority of Bataks are Christians so there are many churches in the area than in the other Indonesian towns and cities. The Batak people themselves are separated into several different groups with distinct cultures and practices from one another. However, one thing that remains similar amongst the Batak people is the architecture of their houses. While there are minor differences, most Batak groups have houses with similar shaped roofs.

With regards to the Batak community, most tourists declared that Lake Toba also has a variety and delicious ethnic cuisine. The tourists learn and taste the delicious food of the Batak. Since the Batak community generally has a distinct culture from the rest of Indonesia, it is reflected in their food as well. One of the famous and popular dishes is the Batak Grilled Pork. Given that the Bataks are mainly Christians, they do not have dietary restrictions like the majority of Muslim population in Indonesia. Some of the villagers also run small eateries at the edge of the cliffs, selling food such as like fried bananas and coffee. It provides convenience to the tourists while enjoying the mesmerizing views of Lake Toba. There are also plenty of eateries surrounding the lake that offers a variety of cuisines from Batak to Sundanese food. Some of the food selections tried by the tourists were the chargrilled fish and the 'sushi of Batak' that were freshly caught from the lake with rice and other dishes.

The following are some of the experiences shared by the tourists on cultural attraction's theme:

The biggest lake in Asia!! Truly a beautiful lake!! You can see "sigale-gale" traditional dance in Samosir Island, buy traditional accessories in Tomok, ride speed boat, enjoy the waterfall, and stay at so many nice hotels there. (Key Informant 14)

Visited this underrated lake in February 2016. An hour cruise took us to the lake's centre and I was amazed by the historical villages and their history - an outstanding jewel. Enjoyed shopping in their huge bazaar area and eaten lunch using my bare hands. (Key Informant 20)

Samosir consists of different aboriginal villages with their own unique culture, kings and wars. I felt curious to visit them all! (Key Informant 11)

Travelers can try the taste of grilled fish mixed with local spices which is called "Natinombur" or try "Naniura", a very typical food which is made from fresh raw fish, lime, and some spices and served without being cooked. That's why Naniura is also called the Sushi of Batak. (Key Informant 18)

Perhaps a lot of people know Parapat as a tourist destination since the colonial era, but other places surrounding Lake Toba will surprise you, like Bakkara Valley, there are river, waterfall, farm, traditional houses, historical Sisingamaraja etc. (Key Informant 10)

Besides the outdoor activities... do not forget to experience their special and unique local culture; as well as some of the best coffee beans that are available here. (Key Informant 9)

\subsection{Conclusion}

There is a growing number of tourists visiting Lake Toba and in tapping into this demand, the management, local community, and government agency must play a vital role in sustaining Lake Toba as a tourism destination. Natural and cultural attractions are the two significant experiences perceived by the tourists while visiting Lake Toba. It is therefore indispensable to acknowledge the substantial contribution that influenced how tourists view Lake Toba as a tourism destination. To ensure the sustainability of natural and cultural attractions in Lake Toba, the tourism supply chain must also collaborate in supporting the government initiatives in promoting the lake. Future research should investigate the interrelationships among the tourist experiences, with other internal and external factors that might influence the number of tourists' arrival in Lake Toba. Moreover, a comparative study could be done to scrutinize any resemblances and metamorphoses of online tourist reviews as well their experiences in other lake tourism destinations. The findings from the study could provide a more comprehensive understanding of the tourists' experiences of lake tourism, particularly in Lake Toba.

\section{References}

1. Compete, Inc. (2006). Embracing consumer buzz creates measurement challenges for marketers retrieved on November 02, 2017 from http://www.cymfony.com/files/pdf/Compete_Spark_1 2_06_Embracing_Consumer_Buzz_Cr eates_Measurement_Challenges.pdf

2. D, Heiderstadt. (2013, October 21). The world's 20 most beautiful lakes. Retrieved on November 10 , 2017 from https://www.fodors.com/news/photos/theworlds-20-most-beautiful-lakes 
https://doi.org/10.31426/ijamsr.2018.1.3.131

I J A M S R

International Journal of Advanced Multidisciplinary Scientific Research (IJAMSR) ISSN:2581-4281

3. Hall, C. M., \& Harkonen, T. U. I. J. A. (2006). Lake tourism: an introduction to lacustrine tourism systems. Lake Tourism: An Integrated Approach to Lacustrine Tourism Systems. Clevedon, Channel View, 3-26.

4. Hall, C. M., \&Härkönen, T. (Eds.). (2006). Lake tourism: An integrated approach to lacustrine tourism systems (Vol. 32). Channel view publications.

5. Jiang, B., \& Chen, P. Y. (2007). An economic analysis of online product reviews and ratings retrieved on Nov 05, 2017 from https://ssrn.com/abstract $=1023302$ or http://dx.doi.o rg/10.2139/ssrn.1023302

6. Jeong, M., \& Mindy Jeon, M. (2008). Customer reviews of hotel experiences through consumer generated media (CGM). Journal of Hospitality \& Leisure Marketing, 17 (1-2), 121-138.

7. Johnson, D. S. (1956). Systematic and ecological notes on the Cladocera of Lake Toba, and the surrounding country, North Sumatra. Zoological Journal of the Linnean Society, 43 (289), 72-91.

8. Law, R. (2006). Internet and Tourism-Part XXI: TripAdvisor. Journal of Travel and Tourism Marketing, 20 (1), 75-77.

9. Lewis, D., and Bridger D. The Soul of the New Consumer. London: Nicholas Brealey Publishing. 2001

10. Lumbanraja, V. (2012). Tourism area life cycle in Lake Toba. Indonesian Journal of Geography, 44 (2).

11. Moedjodo, H., Simanjuntak, P., \& Hehanussa, P. Experience and Lessons Learned Brief for Lake Toba retrieved on November 02, 2017 from http://www.exercicescorriges.com/i_127539.pdf

12. Mudambi, S. M., \& Schuff, D. (2010). What makes a helpful review? A study of customer reviews on Amazon.com

13. Saragih, B., \&Sunito, S. (2001). Lake Toba: Need for an integrated management system. Lakes and Reservoirs: Research and Management, 6 (3), $247-$ 251.

14. Situmeang, R. (2016). Developing System Thinking Approach for Sustainable Destination Management in Lake Toba. In MATEC Web of Conferences (Vol. 70, p. 11004). EDP Sciences.

15. The Jakarta Post (2017, Oct 30). Tourism minister aims to get more international tourists to Lake Toba retrieved on November 13, 2017 from http://www.thejakartapost.com/travel/2017/10/30/tou rism-minister-aims-to-get-more-internationaltourists-to-lake-toba.html

16. Weng, C. Y., Chu, W. T., \& Wu, J. L. (2009). Rolenet: Movie analysis from the perspective of social networks. IEEE Transactions on Multimedia, 11 (2), 256-271.

17. Xie, K. L., Chen, C., \& Wu, S. (2016). Online consumer reviews factors affecting offline hotel's popularity: evidence from TripAdvisor. Journal of Travel and Tourism Marketing, 33 (2), 211-223. 